\title{
Reallocation of Water Resources in the Arab Region: An Emerging Challenge in Water Governance
}

\author{
Kannan Ambalam ${ }^{1}$
}

\begin{abstract}
Water is an integral part of ecosystems. It is essential to earth's living creatures and central to maintaining the earth's ecosystems. In most part of the world, both water quantity and quality problems are becoming more acute, since the limited available water resource are being over-utilized and stressed beyond the sustainability point. The contemporary global water crises including inefficient use and lack of equitable distribution are mainly due to the crises of governance. Water governance emerged as a comprehensive framework by replacing all the existing paradigms including integrated water resource management. Though water governance focuses many aspects in ensuring sustainable use of water resources and its equitable distribution, reallocation of water resources may be most appropriate policy option to achieve these objectives. Reallocation systematically addresses the problems of uneven distribution of water resources across the sectors as well as prevents excessive allocation of water to a particular sector. Based on the secondary sources, this paper analyzes the challenges involved in water governance in terms of water reallocation in the Arab countries where the allocation of water for agriculture is reasonable very high. Addressing water scarcity in the Arab region lies mainly in effectively managing the growing demand. Major water governance challenges with respect reallocation of water resources in the Arab region are tariff, metering and billing, which led to the excessive use in an unprecedented manner.
\end{abstract}

Keywords: Arab Region, Global Water Crisis, Reallocation, Water Governance, Water Management, Water Rights

\section{Introduction}

Water is an integral part of natural environment and ecosystems. It is an essential, non-substitutable, scarce resource in many parts of the world (Jowsey, 2012) and remains one of the key determinants of socio-economic development and human well-being. Today, the global water resources \& its sustainability are under severe pressure than at any time during the existence of this planet (Rodda, 2001) due to unprecedented level of depletion, increasing incidents of pollution and large-scale mismanagement \& inefficient use particularly in agriculture sector (Bouguerra, 2006). As the society becomes complex \& the socio-economic conditions undergoes major transformation, the magnitude and the intensity of human impact on natural resources including water becomes more severe and unsustainable (Solanes \& Andrei, 2006). The carrying capacity of the planet especially its ability to absorb the increasing effects of human activities remains one of the major challenges of development, which in turn affects the process of achieving the core objectives of sustainable development (Baker, 2006) and green economy. The emerging issue of climate change compounds the 
scarcity of water in many parts of the world (Koutsoyiannis, 2011). Hence, water must be protected from pollution and inefficient use through appropriate governance framework and policy options (Hulse, 2007).

Currently, the world is facing a critical situation of water crisis at an unprecedented proportion. Globally, the amount of fresh water withdrawn each year increased from 579 cubic kilometers in 1900 to 3973 cubic kilometers in 2000 (Koutsoyiannis, 2011). Today, water scarcity became the single greatest threat to food security, human health, ecological balances and sustainable development (Seckler, et.al, 1999). Similarly, around 700 million people in 43 countries live below the water-stress threshold. The West Asian countries became the most water-stressed region in the world with average annual availability of about 1,200 cubic metres per person (UNDP, 2006). According to the World Commission on Water, the global water demand will increase by $50 \%$ over the next 30 years and 4 billion people, roughly half of the world's population, will suffer water stress by 2025 . Equally, total world water withdrawn is expected to increase at an unprecedented level of $50 \%$ by 2025 . Over the same period, water for non-agriculture purposes will rise by over $60 \%$. It will be more than $70 \%$ for the domestic use, greatest increases in developing countries (Hulse, 2007).

As world population increases and people's standard of living undergoes dynamic changes, the global demand for water for different purposes increases exponentially (Jowsey, 2012). In most part of the world, both water quantity and quality problems are becoming more acute, since the limited available water resource are being over-utilized and stressed beyond the sustainability point (Bruch \& Jessica, 2011). The declining water quality adversely affects the poor people more than others since the rich consume the required water and have adequate resources to get the quantities they want (UNDP, 2009). In most cases, due to lack of accessibility, poor people are forced to drink water that literally is unfit for human consumption as per the standards specified by the United Nations (UN) specialized agencies (Seckler, et.al, 1999).

In July 2010, the UN through its General Assembly Resolution 64/292 recognized the right to safe water as a human right. Following this, in September 2010, the Human Rights Council declared that right to water is legally binding (Gunawansa \& Loveleen, 2013). Significantly, the global community acknowledges the importance of equitable access to water in realizing all human rights, which are universal, indivisible, interdependent and interrelated. Although the existing legal instruments recognize different human rights, they have not always been explicitly articulated in terms of the basic needs including water. In recent years, a needs-based perspective has been given significance with the adoption of the Millennium Development Goals (MDGs) in 2000. To give further importance, a rights-based approach has been encouraged since 2008 (Gupta \& Louis, 2010), which asserts that humans have a right to clean water and combines human development with human rights (Iza \& Stein, 2009). However, onesixth of world population mostly in developing countries lack access to safe water to ensure better standard of living (Bruch \& Jessica, 2011). This has far-reaching consequences on the socio-economic development of people and their productivity. For example, in developing countries about $80 \%$ of all diseases and more than $30 \%$ of all deaths are related to water-related problems (Kundzewicz, 1997).

The contemporary global water crises including inefficient use and lack of equitable distribution are mainly due to the crises of governance. Under the changing socioeconomic conditions \& climatic and hydrological patterns, sustainable use of water and 
its balanced distribution should be the main focus of water policies. However, the existing water management practices are not able to adequately meet increasing global water demand. In water sector, the conventional policy-making framework and implementation strategies comprehensively failed to respond the dynamic changes experienced in natural resources management. Given the rapidly changing nature of water needs of different sectors, the public policies and institutional arrangements related with water sector are increasingly becoming outdated (Bruch \& Jessica, 2011). In order to ensure sustainable use of water \& its equitable distribution, administrative reorganization, appropriate policy-orientations \& technological innovations are critical in water sector (Hulse, 2007).

Despite the increasing complexities and uncertainties in water resource management system, there are pressing needs for water from different sectors that must be met by the public authorities (Bruch \& Jessica, 2011). However, meeting these critical challenges need effective collaboration among various stakeholders since it involves a wide range of skills, institutions and actors. The contemporary water problems cannot be solved in a sustainable way by confining the policy focus on water resource alone (Solanes \& Andrei, 2006) without understanding the context and exploring interrelated issues in a crosssectoral aspect. Globally, water problems \& water management options are as much a product of the social, economic and institutional contexts of public governance (Moench, et.al, 2003). In a policy perspective, water crises are largely the outcome of human decisions (Lu, et.al, 2014). Therefore, the traditional conventional centralized administrational arrangement must be replaced by decentralized institutional mechanisms, which encourage the participation of stakeholders in decision making process related with water resources (Döckel, 2006). Accordingly, the need to integrate different elements in the governing process of water resources becomes imperative in the changing dynamics of water demand and supply (Solanes \& Andrei, 2006).

Water governance emerged as a comprehensive framework by replacing all the existing paradigms including Integrated Water Resource Management (IWRM). This inclusive approach ensures sustainable use of water and its equitable distribution through appropriate policies and institutional arrangements (Chan, 2009). This changing paradigm, as advocated by the Public Choice Approach of Vincent Ostrum, acknowledges the fact that problem-solving capacity is now widely dispersed over many actors (Lulofs \& Hans, 2010). Accordingly, water governance addresses equity in resource allocation as well as clearly assigns the roles and responsibilities among different stakeholders (Grigg, 2011). Besides, water governance helps in shifting the focus of public institutions from managing water supply to demand and short- term crisis management to long- term planning (UNDP, 2013). Overall, water governance clearly emphasizes on effective provision of sufficient water for poor and marginalized areas, efficient enforcement of water legislation and proper maintenance of water infrastructure, and strengthening the ability of governing institutions and capacity of its personnel to rightly balance competing demands between socio-economic needs and the environmental sustainability (UNDP, 2013).

Though water governance, a paradigm shift in water resources management, focuses many aspects in ensuring sustainable use of water resources and its equitable distribution, reallocation of water resources may be most appropriate policy option to achieve these objectives. Reallocation systematically addresses the problems of uneven distribution of water resources across the sectors. This in turn ensures equitable distribution of water 
and its balanced allocation. Basically, the reallocation mechanism prevents excessive allocation of water to a particular sector, which generally leads to inefficient and unsustainable use. However, water reallocation needs stronger water decisions that are highly complex and controversial in developing countries (Grigg, 2008) due to lack of well-structured and decentralized institutional arrangements. Any delay or irrational decisions on the use and allocation of water would allow for continued unsustainable uses of water in agriculture and will deny the rights of other users for a reasonable share (Bruch \& Jessica, 2011). In a major challenge to public governance, the future water problems may be dictated more by the competition among different water-use sectors than by the actual quantity of water available in a particular region or a country (Sivakumar, 2011). Effectively managing the increasing demands from competing uses and users will test the ability of water governance framework (Söderbaum \& Cecilia, 2011).

The Arab region remains the most water-scarce in the world. However, these limited resources have not been allocated in a balanced manner across the sectors as per the needs. Under this background, this paper analyzes the challenges involved in water governance in terms of water reallocation in the Arab countries where the allocation of water to agriculture is reasonably very high. The World Bank estimates that the irrigated agriculture in Arab countries claims nearly $87 \%$ of the total water withdrawals (World Bank, 2002). Also in this region, the economic cost of the water resources in agriculture is insignificant since it contributes little to national income (Beaumont, 2002). Besides, in Arab region, water scarcity has become one of the most acute environmental challenges. Equally, the governance framework in the region has not been well-developed and the participation of different stakeholders in public governance is very limited. In almost all Arab countries, the distribution of roles and responsibilities is often unclear. Although several government agencies provide water, none manages or governs it (UNDP, 2013). These conditions seriously affect the reallocation of water resources within the framework of water governance. This study attempts to critically analyze different dimensions of reallocation of water resources in Arab region and its challenges in water governance.

\section{Water Governance: A Paradigm Shift in Water Management}

In the era of climate change and mounting pressure on the limited freshwater resources, the 21 st century global water crises are among the most daunting challenge faced by the public administration and governing institutions across the world (UNDP, 2006). The need for sustainable use of water resources and its equitable distribution of water to all underline the critical importance of designing and implementing appropriate policies and practices (Hurley \& David, 2007). The contemporary global water crisis is being considered as a crisis of governance and largely the failure of public institutions to adequately respond to the changing dynamics of water demand-supply equation (UNDP, 2004; GWP, 2000). A strong argument is being made by group of scholars that world is facing water crisis not because of physical scarcities of water, but because of inefficient use of water (Sivakumar, 2011). Equally, recent research on this subject found a direct correlation between lack of access to water and poor governance structures especially in developing countries (Gunawansa \& Loveleen, 2013). Failure to effectively managing the 
increasing demand is more often considered as the result of poor management by the governments (Zetland \& Christopher, 2013).

The need for effectively managing water demand and supply \& restructuring the institutional arrangements governing water resources greatly felt at different levels. The importance of reassessing and modifying the existing paradigms in water sector in conformity with the changing societal and development context was strongly proposed (Söderbaum \& Cecilia, 2011). The Dublin Conference on Water (1992) marked the beginning of setting significant international standards and policy objectives related with water governance. The Freshwater Conference (2001) held in Bonn asked the global community to give major emphasizes on improving water governance. The UN Millennium Assembly strongly encouraged the governments to develop water management strategies to promote both equitable access and adequate supplies of water. Provision of clean water to all the sections of society especially to the marginalized communities found as one of core components of MDGs. This changing focus was endorsed at the World Summit on Sustainable Development (2002) held at Johannesburg (Rogers \& Alan, 2003).

Historically, most water problems were solved through undertaking additional water development projects \& physical expansion, which focuses only on the supply side (Moench, et.al, 2003). These traditional water management practices primarily focused on development of the water resources to supply water of a given quality where it was needed as per the demand. This approach is based on the assumption that water is an infinite resource (RCS, 2010). These conventional practices failed to meet increasing global water demand from competing users (Bruch \& Jessica, 2011). Globally, water management practices continue to be highly inefficient and performed at sub optimal (Sivakumar, 2011). Similarly, these strategies comprehensively failed to ensure sustainable use of water resources and its equitable distribution since it focuses only on balancing demand and supply (Rogers \& Alan, 2003) without giving adequate emphasis on number of broader socio, economic and environmental issues involved in determining the water dynamics of demand and supply (Hoekstra, 2010). These approaches reinforce existing hierarchical organizations without providing adequate space for participation of stakeholders in water management (Moench, et.al, 2003).

Like other natural resources, initially the problems related with water were treated as a 'stand-alone' problem best addressed through technical interventions within a specific context (Kannan, 2012). Even this has been termed as "techno-centric approach" (Sivakumar, 2011). However, the technical solutions applied were found to be unsuitable and completely failed (Currie-Alder, et.al, 2006; Grigg, 2011). This is because of the failure to understand the dynamic process involved in water sector, which have the ability to radically change the specific constraints and contexts. For example, some studies clearly proved that more water infrastructure alone is not the solution to water scarcity (Currie-Alder, et.al, 2006). The increasing economic, hydrologic and technological uncertainties of the future as well as the increasing expectations of community for a better standard of living made these technical approaches as inadequate (Biswas \& Cecilia, 2010). Currently, the increasing complexity of water use system is a major factor in reshaping the contemporary global water management practices, policy options and governance strategies (Moench, et.al, 2003). Since water quantity and quality aspects are multi-sectoral, their related trends, drivers and challenges should be approached as such (Söderbaum \& Cecilia, 2011). 
Finding a permanent solution for the contemporary global water crises is evidently not an issue that can be approached from one direction. It is instead a kind of development challenge that is cross-cutting in nature, which requires participation of stakeholders from within and outside the water sector (Tortajada, 2010) and their combined commitment to share resources, skills, innovations and best practices (Rogers \& Alan, 2003). In the era of globalization, cross-cutting nature of socio-economic problems and trans-boundary aspects of ecological challenges, no single actor has the sufficient knowledge of public policy and strategy inputs to address the rapidly changing societal challenges on one's own. Today, significantly, no actor has the required potential to unilaterally dominate the policy-making arena of public governance in a globalized world (Kooiman, 2003; Tortajada, 2010; Kannan, 2012).

Water cannot be seen as a sector of its own. It is an integral part of the global system and a dynamic matrix. The governing process of water is not immune to the rapid changes that are likely to affect the water sector, either directly and indirectly (Biswas \& Cecilia, 2010). There are numerous factors that affect water availability, demand, supply, withdrawal, consumption pattern, planning and management and water crisis. These are highly interconnected in complex ways and mutually influencing (Sivakumar, 2011). To cope with these emerging challenges in water sector, new forms of governance and institutional rearrangements are needed (Vannevel, 2011). As the limitation of the physical and technical approaches to water resource management failed to address the complex issues, the focus is increasingly shifting towards administrative reforms and institutional restructuring (Saleth, 2006). Therefore, presence of appropriate administrative framework and legislative process are more important. The strategies governing water sector should be multi-sectoral in character and needs to be integrated with the broader socio-economic policy framework (Falkenmark, 2011).

Water governance, an alternative mechanism, emerged as a comprehensive framework to address the complex problems facing the water sector. The core principles of water governance go beyond the narrow perspective paradigms used in water sector including IWRM (Gunawansa \& Loveleen, 2013). Currently, there is no universally agreed definition of water governance. The concept is still evolving (Tortajada, 2010). However, water governance has widely been defined as the range and the process of political, social, economic and administrative systems that are developed to manage water resources and to ensure effective delivery of water services at different levels in an equitable manner (Bakker, 2003; Currie-Alder, et.al, 2006; Chan, 2009; Biswas \& Cecilia, 2010; Hoekstra, 2010). The first World Water Development Report (2003) reiterates this definition and underlines the importance of understanding on how power and authority related with water resources are being exercised and distributed in the society (CurrieAlder, et.al, 2006). As a dynamic concept, water governance includes a comprehensive set of elements and processes. These are administrative mechanisms, legislative policymaking processes \& institutional arrangements, which help stakeholders in articulating priorities, exercising legal rights, meeting obligations \& mediating differences in relation to water resources ( UNDP, 2004; Cleaver \&Tom, 2005; Chan, 2009).

The notions of emerging governance framework are particularly relevant where governments are facing massive challenges and mounting pressures in providing basic services such as water in a more sustainable and equitable manner (Franks, et.al, 2011). Unlike government, the governance framework widely accommodates diverse policy inputs and stakeholders to share resources in achieving number of common objectives, 
which are generally complex and cross-sectoral in nature. This approach minimizes political and social risks, as well as institutional failures and organizational rigidity. In terms of governability, water governance focuses on the capacity of governments to formulate appropriate policies and design effective institutional arrangements that are socially and culturally accepted. Accordingly, it also emphasises on the ability and capability of government institutions to mobilise required resources in a coherent manner and to ensure public participation in effectively governing water resources (Rogers and Alan, 2003; Solanes \& Andrei, 2006).

In an attempt to include diverse inputs, the concept of water governance covers a wide range of competing and disparate ideas across the developmental sectors (Franks, et.al, 2011). As an inclusive framework, water governance is concerned with not only political, social and economic organisations and institutions but also their complex relationships in effectively governing the water sector (GWP (SAS), 2002; Rogers \& Alan, 2003). Accordingly, the architecture of water governance framework has been built on the four pillars of a dynamic social system. These are social, economic, environmental and political dimensions (Tropp, 2005). The social aspect refers to equitable distribution of water resources. Efficient water use and its critical role in economic growth are some of the key economic aspects of water governance (World Bank, 2003). The political dimension involves water rights and public participation in decision making process related with water resources. The sustainable water use and the importance of protecting ecosystem are related with environmental aspects (Miranda, et.al, 2011).

Today, in many countries, framework of water governance is in a state of confusion, with lack of appropriate institutions or fragmentation of decision-making process and authorities resulting in the existence of a number of unsolved water problems (Grigg, 2011). Relatively few developing countries have an integrated water policy, while many have highly pluralist water law systems governing water sector (Gupta \& Louis, 2010). Most of these policy instruments are not effectively being implemented. Also in a number of countries, the feasibility and appropriateness of existing legal arrangements and institutional responses is at best uncertain and inadequate (Bruch \& Jessica, 2011). Generally, the problem in many developing countries is that there are marked limits on the capacity of government agencies to effectively regulate the water sector (UNDP, 2006). While in this changing global development landscape, the increasing socio, economic and environmental pressures are largely being felt by developing countries. Due to various reasons, these countries are less equipped to manage and adapt to the rapid changes that are being experienced in water sector (Söderbaum \& Cecilia, 2011). The countries in the Arab region also have similar problems. However, considering the existing water scarcity in the region and the nature of increasing demand for water from the non-agriculture sector, these institutional issues will further complicate the process of achieving sustainable development and green economy. These will not only reinforce the need for reallocation of water resources but also remain as major challenge to undertake reallocation of water in the Arab region.

\section{Water in the Arab Region: A Development \& Security Challenge}

Shortage of water has always been considered a security issue in the Arab region (Bilgin, 2005) since it is in an alarming state and reaching a critical point (UNDP, 2013). Water demand in these countries increased dramatically as a result of increasing 
population growth, substantial improvements in the standard of living, large scale industrialization, infrastructure development and concerted efforts made to increase food self-sufficiency in some of the Arab countries (World Bank, 2005). This region has an estimated 300 billion cubic metres of water, which is less than $1 \%$ of the world's total water resources. On the other hand, it has $5 \%$ of the world's population (UNDP, 2009). Over the past few decades, the Arab region experienced a major development boom. Some of the Arab countries initiated ambitious economic development plans and undertook rapid urbanization, which witnessed massive transformation in the urban landscapes across the region (Tropp \& Anders, 2006). Urbanization has risen from nearly $45 \%$ of the population in 1980 to $56 \%$ in 2010 and is expected to exceed $60 \%$ in 2020 (UNDESA, 2011). As a sign of improved social development and standard of living, water supply has been made accessible to a large section of the population (World Bank, 2005).

Like in many other countries, water scarcity in the Arab region is the product of public policies, which encouraged overuse of water through subsidies and under pricing (Zetlanda, et.al, 2013). In order to respond the unprecedented rise in population growth and food demand, many countries in the region prioritized agricultural production and food self-sufficiency through undertaking large scale expansion of arable land and irrigation network. A disproportionately large share of available freshwater is being used in agriculture, but it is accompanied by an intensive use of chemical fertilizers \& pesticides (Tropp \& Anders, 2006). Between 1996 \& 2006, the Arab countries used $71 \%$ of their available water resources compared to a global rate of $6.3 \%$. In an unsustainable manner, more than two-thirds of this was allotted to agriculture (UNDP, 2009). Agricultural water use rose from about 160 billion cubic metres in 1995 to more than 200 billion in 2003 (UNDP, 2013). For example, since early 1970s, Saudi Arabia initiated a number of policy measures to ensure food self-sufficiency. These include provision of up to 1,000 acres of free land as well as machinery and equipment at a subsidized price up to $50 \%$. The cultivation area increased from under 400,000 acres in 1976 to more than 9 million acres in 2003 (Ray, 2003).

In the Arab region, irrigation water is mainly supplied by groundwater. The rapid expansion of irrigated areas resulted in substantial increases in groundwater abstraction. It has been even termed as groundwater "mining" (Olmstead, 2010). Irrigation water is widely subsidized and largely sold below operational and maintenance expenses despite the increasing economic and environmental costs of overexploitation and inefficient use (UNDP, 2013). The introduction of mechanized pump-wells and construction of massive irrigation networks nearly doubled the amount of irrigated land between 1965 \& 1997 (Wessels, 2009). In 1997, in Qatar about 98\% of ground water withdrawal is made for agricultural purposes (UNCCD, 2000). This creates unbalanced equilibrium, which leads to intrusion of seawater along the shoreline, causing salinization of coastal agricultural lands. The Arab region's present rate of groundwater withdrawal is unsustainable since it outpaces the rate of replenishment and will rapidly deplete the aquifers (Nasr, 1999). Globally, more than $75 \%$ of underground water is nonrenewable, as the process of replenishing takes centuries or more (Jowsey, 2012). Also it is impossible to clean up ground-water pollution (Stauffer, 2013). Despite the significant increase in water allocation, performance of agriculture sector is minimal in many Arab countries (Dabour 2006). The irrigation efficiencies in the Arab region are as low as 30- 
$40 \%$ (El-Ashry, \& Zeitoon, 2010) due to overuse of water through unsustainable irrigation techniques and inefficient drainage systems (Nasr, 1999).

Poor management and inefficient use of water for irrigation resulted in salinisation, alkalinisation, water logging and nutrient depletion in the Arab region. As a result, the productivity of land and water resources is steadily declining and environmental sustainability is at higher risk (ICARDA, 2003). Globally, salinization affects $20 \%$ of the world's irrigated land by significantly reducing crop production leading to food insecurity (Mohammad, 2002). Nearly 43 million ha of irrigated land in the Arab countries are seriously affected by various ecological degradation processes (Nasr, 1999). About 2 million ha of irrigated land area in Saudi Arabia and 33.6\% of the cultivated land of Bahrain are moderately salinised (GRC, 2007).

Falling groundwater tables and reduced river flows in the region have farreaching consequences for the social and economic development of these countries. Equally, there is an exponentially growing demand on water resources for nonagricultural purposes (UNDP, 2009).Due to their extreme water scarcity, most countries in the region find it very challenging to cope with the increased water demands. Domestic water consumption per capita varies considerably in the Arab region, both among and within countries. For example, in the Gulf Cooperation Council (GCC) countries, it ranges from 300 litres per day to 750, which is among the world's highest (World Bank, 2005). In order to sustain the current level of industrialization as well as future expansion, it is necessary to ensure continuous water supply and balanced distribution.

Largely, the governments in this region didn't apply appropriate policy options for conservation and efficient use of limited available water resources as well as managing increasing demand in an efficient manner (UNDP, 2013). Though the efficiency of energy usage in most part of the world has steadily improved, the water sector has not made commensurate progress due to inappropriate policies and governance practices (Biswas \& Cecilia, 2010). No systematic efforts have been made to curtail the wasteful practices and inefficient use by farmers and wealthy urban dwellers that keep water demand high (Alterman \& Michael, 2010). The micro-irrigation, the more efficient water conservation technique is practiced only $2.8 \%$ of irrigated area. Surface irrigation is widely practiced covering $80 \%$ of the irrigated area, followed by sprinkler irrigation (FAO, 2011). The process of mapping groundwater is an instrument to determine the conditions of ground water resources. However, this has not been widely undertaken (Alterman \& Michael, 2010).

In the Arab region, under these complex conditions \& increasing competing claims for the limited water resources, it will be unsustainable to maintain current levels of water allocation to agriculture (Tropp \& Anders, 2006). Today, the best policy option is a gradual reallocation of water from agriculture to industry and domestic uses that can provide a higher economic return. Also reallocation is termed as optimization of water allocation among these three domains: agricultural, industrial and domestic (UNDP, 2009). This will ensure not only sustainable use of water but also equitable distribution of these limited resources. This will be a more realistic, pragmatic \& long-term sustainable policy option to conserve \& efficiently manage water resources as well as to protect the environment and its sustainability. Instead of augmenting new supply to meet the increasing demands, focus should be in conservation of existing supplies and 
reallocation of water rights (Howitt \& Hansen, 2005). The legal and institutional changes should be designed to facilitate voluntary reallocation (MacDonnell, 1995).

\section{Need for Reallocation of Water Resources}

The sustainable utilization \& equitable distribution of limited water resource requires balancing the long-term protection of available water resources and the increasing requirements of the society (RCS, 2010). However, from time immemorial the governments across the world bridged the growing gap between supply and demand by changing the supply side of the equation. The large engineering works in the form dams, reservoirs and vast irrigation networks developed by the governments in the 20th century reflects this approach. Irrespective of regional and climatic variations, this engineering approach substantially helped the agriculture sector since it consumes more than $80 \%$ of available water resources. On the other hand, an overriding emphasis on socio-economic development and rising level of awareness on better standard of living has led to increased commercial, industrial and household demands for water (Bruch \& Jessica, 2011). The increasing competition for water from non-agriculture sectors are progressively reaching at an unprecedented level (Hulse, 2007). Even these increases are relatively much faster than those for irrigation (Sivakumar, 2011). Today, the major governance challenge is how to balance the increasing competing claims of different water users (UNDP, 2006) in a situation where nearly $80 \%$ of water is being used for agriculture.

The growing competition and the need for adequate water resources to maintain the ecological balance are further complicated by other broad societal objectives, supported by global and regional declarations, such as equity in access and ensuring food security (Molden \& Sakthivadivel, 1999). However, augmentation of new water supplies remain expensive and unsustainable (Howitt \& Hansen, 2005). Conservation and reallocation of water resources reduces the costs and provide more flexibility (National Research Council, 2004). Therefore, reallocation of water can be better policy option in terms of costs as well as to move water to the highest economic use. They can also result in reduced risk when compared with traditional approaches (McCrea \& Ernest, 2007). Also water reallocation will ensure the desire levels of environmental protection and ecological integrity (RCS, 2010). Similarly, the reallocation process ensures efficient utilization of water resources (Ecology \& West Water Research LLC, 2004). Water allocation has often been a contentious issue and this is likely to increase in future as competing demands rise while declining available water resources (RCS, 2010).

Reallocation of water resources goes beyond the issue of meeting basic needs and ensuring equity in distribution since it mainly focuses on how the limited water resources can best be divided among different competing users. Water reallocation has three dimensions. These are how water resources are being shared, risks and burdens are being distributed and responsibilities for causing environmental problems are being made. Reallocation also depend on a number of factors including the role of social actors, coalitions, and movements in debating, promoting and pushing for these ideas, mobilizing resources, science and technology and actually ensuring implementation (Gupta \& Louis, 2010).

The transfer of water rights is the core aspect of reallocation of water resources. This involves transfer of water right or use of water from one person or entity to another. It 
includes any associated changes to one or more elements of the transferred water right. The elements will depend upon the planned use of the water right by the stakeholders involved in reallocation. These include a change in place of use, purpose of use, geographical point of diversion or withdrawal, and season of water use. For example, a transfer from an agricultural user to a municipality usually involves changes to all the elements of a water right. In case a change from agriculture to instream flow requires a change in place of use, purpose of use, \& elimination of the point of diversion (McCrea \& Ernest, 2007).

In Arab countries, there are immense pressures to reallocate water from agriculture, with low value-added per cubic metre, to other sectors, high value-added (UNDP, 2013). However, little improvement has been made in fostering an integrated approach in water management. The existing institutional arrangements in the area of environmental management are inadequate to achieving integrated and participatory sustainable development (ESCWA, 2003). It remains a major water governance challenge for the Arab countries. Water governance is the best framework to analyze the challenges involved in reallocation of water resources. This broader approach accommodates a large number of policy and governance issues and inputs, which otherwise will not fit in the other paradigms including the integrated water resource management (Gupta \& Louis, 2010).

\section{Water Reallocation: A Governance Issue in the Arab Region}

Despite consistent efforts made by the international community at different levels, the gap between water supply and demand has been widening (UNDP, 2013). Global water use has been growing much faster than world population for at least a century and the same trend is continuing. Over the past hundred years population quadrupled, while water use grew by a factor of seven (Kundzewicz, 1997; UNDP, 2006). The water crisis including inequities in distribution not only poses threats to humans but also affects the ecological balance (Lu, et.al, 2014). Meeting these increasing water requirements of a growing global population while protecting the natural ecosystems and its sustainability on which life itself depends is a critical condition for sustained human development and accelerated economic growth (UNDP, 2006). This in fact remains major challenge for public governance. In the water-scarce Arab region, using water resources equitably and reasonably is a key challenge of water governance (UNDP, 2013). Limited availability, over-exploitation of ground water, poor distribution among users and increasing demand from non-agriculture sectors characterize dynamics of water use in the Arab countries (UNDP, 2009).

Addressing water scarcity in the Arab region lies mainly in effectively managing the growing demand. Most of the water demand comes from agriculture. This in fact needs a major shift to a more diversified economy (Wessels, 2009). Like the global trend, agriculture currently dominates water use in the Arab region (UNDP, 2013). Any decisions regarding how much water is allocated to this sector are highly political (Gupta \& Louis, 2010). In an attempt to prioritize state security and regime stability, governments in Arab countries failed to adopt long-term policies on the inter-related issues of water and food security. In the beginning, Arab countries considered water as non-military issue and adopted traditional practices in water harnessing and distribution (Bilgin, 2005). Some of the Arab countries grow water-intensive products to achieve 
food 'self-sufficiency' without considering the environmental sustainability of water sources and ecological balance (Pfeifer, 1993).

However, indicators of agricultural performance clearly show that water management is unsustainable. This is due to deteriorating infrastructure, lack of good governance practices in water sector, low irrigation service fees and poor participation of water users in maintenance water infrastructure and decision-making process. The growing competition over water resources are cause for more concern. In order to ensure over all socio-economic development, arguments are being made for reallocating water supplies from one sector to another, to boost economic development. However, such decisions have extensive socio-economic and political ramifications (Molle \& Berkoff, 2005). Appropriate water governance is the only way out of a rapidly deteriorating situation in water resource management in the Arab region (UNDP, 2013) since each sector has its own claims \& arguments on the need of more water.

Water rights are widely dispersed over policy sectors, governmental agencies and developmental actors (Lulofs \& Hans, 2010). Water rights represent socially accepted and enforceable claims to water. They define the terms allowing for the removal of water from its natural environment, the use of water in a natural source and the management of water flows (UNDP, 2006). Clear identification of these rights is important to undertake reallocation of water resources. However, in the Arab countries, there is lack of clarity with respect to these rights among stakeholders (Bruch \& Jessica, 2011). Unclear water rights and lack of infrastructure management procedures lead to confusion among government agencies and water users about entitlement to water. Also in most Arab countries, there is lack of appropriate legal instruments to effectively regulate water sector (UNEP, 2010). Also no Arab country achieved the desired balance between demand and supply. This is because of not only rising demand and scarcity, but also governance obstacles such as weak institutional arrangements, unequal water access, and inefficient enforcement of regulations (UNDP, 2013).

In terms of a shared ecosystems approach, the only option to find a sustainable solution to water scarcity in the Arab countries is the active involvement and cooperation of communities (Wessels, 2009). In the last few decades, some of the Arab countries have undertaken administrative reform in their agricultural \& water sectors. However, it has not been focused on reallocation of water resources. Growing awareness on the need for decentralization of power \& authority and participation of farmers and other water users in water management has resulted in adoption of participatory irrigation management in several Arab countries. For example, Egypt, Jordan, Libya, Morocco, Oman, Tunisia and Yemen have promoted water user associations as active partners in developing, operating and maintaining irrigation systems. Such an active participation of users helps determine service levels, charges \& water allocations (World Bank, 2007). However, such practices don't exist in other Arab countries.

Arab countries lack comprehensive legislation and properly functioning institutions with respect to natural resources management including water. The land rights also need to be formalized since more secure land tenure could actively encourage farmers to invest in improved agricultural practices \& water conservation techniques (Tropp \& Anders, 2006). This will largely help in undertaking reallocation of water resources. In order to regulate groundwater extraction, metre and tariff system should be introduced. Efficient agricultural techniques and water conservation practices should be promoted through regulations, institutional reform, tax exemptions, subsidies and capacity building. Key 
capacities for adaptive governance for climate induced water scarcity are underdeveloped. And Arab countries need to foster regional cooperation on adapting to climate change (UNDP, 2013) that will address the gaps in uneven distribution of water resources.

Research \& Development (R \& D) are not adequately institutionalized. The action-oriented researches are not well articulated (Rached \& Dina, 2000). Generally, farmers lack the capacity to apply appropriate technologies for water conservation. There is also a lack of economic incentives for farmers to invest in new irrigation or rainfed technologies. Though water saving is highly prioritised in the region, many farmers receive public subsidies that result in more water withdrawals for irrigation instead of more efficient water use (Tropp \& Anders, 2006). A gradual attitudinal change needs to be encouraged in order to shift the disproportionate allocation of water to the agriculture sector. Major policy concerns are tariff, metering and billing, which led to the excessive use in an unprecedented manner (World Bank, 2005). Better procedures are urgently needed for assessing irrigation performance, along with better systems to manage water conveyance, allocation and distribution (Placht, 2007). Arab countries should increase irrigation efficiency, as the opportunity to save water is notably higher than in other sectors (Mehmet \& Bicak, 2002). A comprehensive and multi-sectoral approach is urgently needed to undertake the reallocation of water resources. Any delay by the Arab countries in this direction will cost the processes of achieving sustainable development in this region and will largely compromise the ability of its citizens to have a betterment standard of living.

\section{Conclusion}

Water is an integral part of natural environment and ecosystems. It is an essential, non-substitutable, scarce resource in many parts of the world and remains one of the key determinants of socio-economic development and human well-being. Today, the global water resources \& its sustainability are under severe pressure than any time during the existence of this planet. In the Arab region, under the complex conditions \& increasing competing claims for the limited water resources, it will be unsustainable to maintain current levels of water allocation to agriculture. Today, the best policy option is a gradual reallocation of water from agriculture to industry and domestic uses that can provide a higher economic return. Falling groundwater tables and reduced river flows in the region have serious far-reaching consequences for the social and economic development of these countries. Equally, there is an exponentially growing demand on water resources for non-agricultural purposes. Major water governance challenges with respect reallocation of water resources are tariff, metering and billing which led to the excessive use in an unprecedented manner. The future research on this critical subject of public governance needs to focus on the following areas. Will the proposed allocation of water from agriculture affect the food security in the region considering the current rate of population growth; Will the proposed reallocation with ensure both quantity and quality of water supply for the domestic users; Whether the Arab countries can undertake reallocation process with available technology in terms of ground water mapping and geographical information system; Will the traditional techniques and indigenous knowledge help in reallocation process; Considering the number of transboundary nature of rivers in the region, how does the reallocation process address the problems inter-sate river disputes. 


\section{Acknowledgments}

The views presented are those of the author and do not represent those of the institutions with which he is affiliated.

\section{Conflicts of Interest}

The author declares no conflicts of interest.

\section{Reference}

Alterman, Jon B. \& Michael Dziuban (2010) Clear Gold: Water as a Strategic Resource in the Middle East, Washington, D.C.: Center for Strategic and International Studies.

Bakker, K. (2003) Good Governance in Restructuring Water Supply: a Handbook, Federation of Canadian Municipalities, Ottawa.

Baker, Susan (2006), Sustainable Development New York: Routldge.

Bilgin, Pinar (2005), Regional Security in the Middle East: A Critical Perspective, London: Routledge.

Biswas, Asit K. \& Cecilia Tortajada (2010) Future Water Governance: Problems and Perspectives, International Journal of Water Resources Development, 26(2):129-139.

Bouguerra, L., (2006), Water under Threat. London: Zed Books.

Bruch, Carl \& Jessica Troell (2011), Legalizing Adaptation: Water Law in a Changing Climate Water International, 36(7):828-845.

Chan, N. W. (2009), Issues and Challenges in Water Governance in Malaysia, Iranian Journal Environmental Health Science Engineering, 6 (3):143-152.

Cleaver, Frances \& Tom Franks, (2005), Water Governance and Poverty: A Framework for Analysis, BCID Research Paper No.13, Bradford Centre for International Development.

Currie-Alder, Bruce, Lorra Thompson \& Rocio Bustamante (2006), Insights on Water Governance: Research in the Middle East/North Africa and Latin America, IDRC.

Dabour, N. (2006), Water Resources and their Use in Agriculture in Arab Countries, Journal of Economic Cooperation 27 (1): 1-38.

Döckel, J. A. Max (2006), The Possibility of Trade in Water Use Entitlements in South Africa under the National Water Act of 1998, In: Perret, Sylvain Stefano Farolfi \& Rashid Hassan, (eds), Water Governance for Sustainable Development, London: Earthscan.

Ecology and West Water Research, Washington State Department (2004) Analysis of Water Banks in the Western States. Ecology Publication Number 04-11-011. July 2004.

Economic and Social Commission for West Asia (ESCWA), (2003), Governance for Sustainable Development in the Arab Region: Institutions and Instruments for Moving beyond an Environmental Management Culture (New York: ESCWA.

El-Ashry, M., N. Saab, \& B. Zeitoon, eds. (2010), Arab Water: Sustainable Management of a Scarce Resource. Beirut: Arab Forum for Environment and Development.

Falkenmark, Malin (2011) Early focus on Water Strategies for The Twenty-First Century: IWRA as an Interdisciplinary Forerunner, Water International, 36(7):776-781.

FAO (2011) Global Food Price Monitor: With Focus on the Horn of Africa, FAO, Rome.

Franks, Tom Franks, Hassan Bdliya \& Lawrence Mbuya (2011) Water Governance and River Basin Management: Comparative Experiences from Nigeria and Tanzania, International Journal of River Basin Management, 9(2): 93-101.

Gulf Research Centre (GRC), (2007) Green Gulf Report, Dubai: GRC.

Grigg, Neil S. (2008) Integrated Water Resources Management: Balancing Views and Improving Practice, Water International, 33(3): 279-292.

Grigg, Neil S. (2011) Water Governance: from Ideals to Effective Strategies, Water International, 36(7):799-811.

Gunawansa, Alsanga \& Loveleen Bhullar (2013) Introduction, In: Gunawansa, Alsanga, Loveleen Bhullar, Sonia Ferdous Hoque (eds), Water Governance: An Evaluation of Alternative Architecture, Cheltenham (UK): Edward Elger Publicity Limited.

Gupta, Joyeeta \& Louis Lebel (2010) Access and Allocation in Earth System Governance: Water and Climate Change Compared, International Environmental Agreements, 10:377-395.

GWP (Global Water Partnership) (2000), Towards Water Security: A Framework for Action, GWP, Stockholm, Sweden. 
GWP SAS (Global Water Partnership South Asia) (2002 ), Dialogue on Effective Water Governance, Battaramulla, Sri Lanka.

Hoekstra, Arjen Y. (2010) The Global Dimension of Water Governance: Why the River Basin Approach Is No Longer Sufficient and Why Cooperative Action at Global Level Is Needed, Water 3: 21-46.

Howitt, R. \& K. Hansen. (2005) The Evolving Western Water Markets, Choice Magazine. ${ }^{\text {st }}$ Qtr. 2005.

Hulse, Joseph H. (2007) Sustainable Development at Risk: Ignoring the Past, Ottawa: International Development Research Centre

Hurley, Joe \& David Mercer (2007) Sustainable Water Systems and Household Practices, In: Nelson, Anitra ed, Steering Sustainability in an Urbanizing World: Policy, Practice and Performance, Hampshire: Ashgate Publishing Limited, pp.111-124.

International Center for Agricultural Research in the Dry Areas and Arab Center for the Study of Arid Zones and Dry Lands,(ICARDA) Integrated Natural Resource Management for Combating Desertification in West Asia, Pilot Projects Proposal, Prepared for the Sub-Regional Action Programme (SRAP) for West Asia of the UN Convention to Combat Desertification (UNCCD), Manama : ROWA/UNEP, 2003.

Iza, A \& Stein, R, eds (2009), Rule: Reforming Water Governance, Gland, Switzerland: ICUN.

Jowsey, Ernie (2012), The Changing Status of Water as a Natural Resource, International Journal of Sustainable Development \& World Ecology, 19 (5): 433-441.

Kannan, A. (2012) Global Environmental Governance and Desertification: A Study of Gulf Cooperation Council Countries, New Delhi: The Concept Publishers.

Kooiman, J. (2003) Governing as Governance, London: Sage Publications.

Koutsoyiannis, D. (2011) Scale of Water Resources Development and Sustainability: Small is Beautiful, Large is Great, Hydrological Sciences Journal, 56(4): 553-575.

Kundzewicz, Zbigniew W. (1997) Water Resources for Sustainable Development, Hydrological Sciences Journal, 42(4): 467-480.

Lu, Flora, Constanza Ocampo-Raeder \& Ben Crow (2014), Equitable Water Governance: Future Directions in the Understanding and Analysis of Water Inequities in The Global South, Water International, 39 (2): 129-142.

Lulofs, Kris \& Hans Bressers (2010) Innovations in water management requiring boundary spanning: roots and concepts In Bressers, Hans \& Kris Lulofs eds, Governance and Complexity in Water Management: Creating Cooperation through Boundary Spanning Strategies Cheltenham, UK: Edward Elgar

MacDonnell, L.J. (1995), Water Banks: Untangling the Gordian Knot of Western Water, Mineral Law Institute, University of Colorado.

McCrea, Mary E. \& Ernest Niemi (2007) Technical Report on Market-Based Reallocation of Water Resources Alternative: A Component of the Yakima River Basin Storage Feasibility Study, Washington State Department of Ecology.

Majlesi, M., \& Yazdanbakhsh (2008). Study on Wastewater Treatment Systems in Hospitals of Iran Iranian Journal Environmental Health Science Engineering, 5 (3): 211-215.

Mehmet \& H.A. Bicak ( 2002), Modern and Traditional Irrigation Technologies in the Eastern Mediterranean. Ottawa: International Development Research Centre.

Miranda, L., M. Hordjik, \& R.K. Torres Molina. (2011) Water Governance Key Approaches: An Analytical Framework. Literature Review 4:1-23.

Moench, Marcus, Ajay Dixit, S.Janakarajan, M.S.Rathore \& Srinivas Mudrakartha (2003) The Fluid Mosaic: Water Governance in the context of Variability, Uncertainty and Change, Kathmandu: Nepal Water Conservation Foundation.

Molden, David \& R. Sakthivadivel (1999), Water Accounting to Assess Use and Productivity of Water, Water Resources Development, 15(1/2): 55- 71.

Molle, F., \& J. Berkoff (2005) Cities versus Agriculture: Revisiting Intersectoral Water Transfers, Potential Gains, and Conflicts, Comprehensive Assessment Research Report 10. Colombo: International Water Management Institute.

Mohammad Al-Attar, (2002) Role of Biosaline Agriculture in Managing Freshwater Shortages and Improving Water Security, Dubai: International Center for Biosaline Agriculture (ICBA).

Nasr, M.(1999) Assessing Desertification and Water Harvesting in the Middle East and North Africa: Policy Implications, Policy Paper no. 10, Center for Development Research, Bonn University, Germany.

National Research Council of the National Academies (2004), Managing the Columbia River: Instream Flows, Water Withdrawals and Salmon Survival, Washington, D.C: National Academies.

Olmstead, Sheila M.(2010) The Economics of Managing Scarce Water Resources, Review of Environmental Economics and Policy 4(2): 179-198 
Pfeifer, K. (1993) Does Food Security Make a Difference? Algeria, Egypt and Turkey in Comparative Perspective, In: B. Korany, P. Noble and R. Brynen (eds) The Many Faces of National Security in the Arab World, London: Macmillan.

Placht, M. (2007) Integrated Water Resource Management: Incorporating Integration, Equity, and Efficiency to Achieve Sustainability. IDEAS, October.

Rached, Eglal, \& Dina Craissat, eds. (2000), Research for Development in the Middle East and North Africa, Ottawa: International Development Centre.

Ray, Daryll E.(2003), Income-rich Saudi Arabia Prefers Grow-their-Own Food Security, MidAmerica Farmer Grower, 20(12): 137.

RCS (Ramsar Convention Secretariat) (2010) Ramsar Handbook 10: Water Allocation and Management, Gland (Switzerland): Ramsar Convention Secretariat.

Rodda, John C (2001), Water under Pressure, Hydrological Sciences Journal 46(6): 841-854.

Rogers, Peter \& Alan W Hall (2003) Effective Water Governance, Technical Committee Background Papers, Stockholm: Global Water Partnership.

Saleth, R. Maria (2006) Understanding Water Institutions: Structure, Environment and Change Process, In: Perret,Sylvain Stefano Farolfi and Rashid Hassan, (eds) Water Governance for Sustainable Development, London: Earthscan.

Seckler, David, Randolph Barker Upali Amarasinghe (1999) Water Scarcity in the Twenty-first Century, Water Resources Development, 15(1/2): 29-42.

Sivakumar, Bellie (2011) Water Crisis: From Conflict to Cooperation-an Overview, Hydrological Sciences Journal, 56(4): 531-552.

Söderbaum, Peter \& Cecilia Tortajada (2011) Perspectives for Water Management within the Context of Sustainable Development, Water International, 36(7): 812-827.

Solanes, Miguel \& Andrei Jouravlev (2006) Water Governance for Development and Sustainability, Santiago: United Nations Publication.

Stauffer, Julie (2013) The Water Crisis: Constructing Solution to Freshwater Pollution, London: Routledge.

Tortajada, Cecilia (2010) Water Governance: Some Critical Issues, International Journal of Water Resources Development, 26(2): 297-307.

Tropp, H. 2005. Building New Capacities for Improved Water Governance, Paper presented in the Council for Scientific Industrial Research International Symposium on Ecosystem Governance, 10-13 October, Kwa Maritaine, South Africa.

Tropp, Håkan \& Anders Jägerskog (2006), Water Scarcity Challenges in the Middle East and North Africa (MENA), Thematic Paper, Human Development Report 2006 - Water for Human Development, Stockholm International Water Institute.

UNCCD Secretariat (2000), The National Report of the State of Qatar on the UNCCD Implementation, Bonn.

UNEP (2006), Training Manual on International Environmental Law, Nairobi: UNEP.

UNEP (2010), Environmental Outlook for the Arab Region: Environment for Development and Human Welfare, Nairobi: UNEP.

UNDP (2004), Water Governance for Poverty Reduction. Key Issues and the UNDP Response to Millennium Development Goals, New York: UNDP.

UNDP (2006) Beyond Scarcity: Power, Poverty and the Global Water Crisis, Human Development Report, 2006, New York.

UNDP (2009) Challenges to Human Security in the Arab Countries, Arab Human Development Report 2009, New York: UNDP.

UNDP (2013) Water Governance in the Arab Region: Managing Scarcity and Securing the Future, New York: UNDP.

UNDESA (United Nations Department of Economic and Social Affairs) (2011) World Population Prospects, the 2010 Revision, New York.

Vannevel, Rudy (2011) Consequences of Increasing Environmental Complexity in the Water Domain, International Journal of Water Resources Development, 27(4): 677-691.

Wessels, Joshka (2009) Water Crisis in the Middle East: An Opportunity for New Forms of Water Governance and Peace, The Whitehead Journal of Diplomacy and International Relations 10:131-142.

World Bank (2003) Kingdom of Morocco: Cost Assessment of Environmental Degradation. Washington, DC: World Bank.

World Bank (2005) A Water Sector Assessment Report on the Countries of the Cooperation Council of the Arab States of the Gulf, Washington, D.C: World Bank.

World Bank (2007) Making the Most of Scarcity: Accountability for Better Water Management in the Middle East and North Africa, MENA Development Report, Washington, DC.

Zetlanda, David \& Christopher Gasson (2013), A Global Survey of Urban Water Tariffs: Are they Sustainable, Efficient and Fair?, International Journal of Water Resources Development, 29 (3): 327-342. 